\title{
The Study of the Phenomenon of Favoritism Revisited
}

\author{
Paramonova S. P. \\ Department of Sociology and Political Science, Perm National Research Polytechnic University, Russia
}

Copyright $\subset 2017$ by authors, all rights reserved. Authors agree that this article remains permanently open access under the terms of the Creative Commons Attribution License 4.0 International License

\begin{abstract}
The article examines the socio-cultural phenomenon of favoritism as a social institution. It analyzes the role of a favorite both in large and small groups. The main theoretical and methodological approaches to the study of the phenomenon of favoritism are presented, as well as the methodology and the methods of analyzing favoritism in groups. The indicators for the analysis of favoritism in a group are the types of moral consciousness within the context of the group role structure, namely a favorite. The article states a problem of studying favoritism, exemplified by the role concept of personality in relationship with moral consciousness.
\end{abstract}

Keywords Favoritism, Role Theory of Personality, Society, Types of Moral Consciousness, Disposition, Social Identity Theory

\section{Introduction}

In the framework of the current system of socio-humanitarian knowledge, the issue of favoritism is customarily referred to the sphere of social psychology. Professionals enforce a disciplinary latent taboo on sociological study of the favoritism. The scientific community is holding the latent provision with an internal discipline. However, a broader consideration of social processes makes us understand that favoritism manifests in the ratio of global leaders and their satellites, in the game of their unities and the unions' decays.

The phenomenon of favoritism is a problem of behind-the-scenes relationships. It is no coincidence that the problem is referred only to the socio-psychological relationships in a collective, which is only partly correct. The phenomenon is both a social and a socio-psychological one. A close examination of favoritism highlights that it manifests itself not only in a person's inner circle behind a leader in the team, but also in every institutional administration affiliated to the government (e.g. the favorite-selected investments of funds in nano and space technologies, or in the military industrial complex, or in the election campaign, etc.).

In the theory of favoritism, the topic can be presented in a historical perspective with the records of some favorite financiers who sponsored kings to wage wars of aggression. In Portugal and Spain, capital from conquests and trade was invested in religious buildings and the acquisition of luxury goods. Nations that conquered others became less active focusing on hedonism. Later, merchants in France and Britain invested in industry, trade and finance. Activeness is determined by pragmatism, and the world follows the route of increasing rationality [1] (Weber M. 1990). The Western Modern I society strives at the seizure of new territories, involving the peoples of traditional societies into the global economy, but on the antagonistic basis in the developing world-system [2] (Wallerstein I. 2016).

The theme of favoritism on the sociological level can be extracted from the universal context, i.e. comparison of different societies and determining the time and place of the communities' actions. As it becomes evident, the problem of favoritism comprises three levels of analysis: macro-, meso- and micro-level. Favoritism is personalized: the wily politician Count-Duke of Olivares, Duke of A. de Richelieu, the "White Hawks" of the military industrial complex under politicians of nowadays. Personalities of favoritism cannot be excluded from the analysis, but we also cannot reduce the analyses entirely to them. With the weakening of religious influences and the transition to secular forms of consciousness, groups of ideologues move out who, by Manheim, are fighting for the influence on the authority [3] Manheim K. (1994).

Sociology studies the attitudes of groups and strata of the society towards favorites, their assessment of favorites' positive or negative impact on the historic development, as well as on the modern system of states. Social psychology (motives of favorites' behavior) and sociology (the consequences of individual and group favorites' actions in practice) are certainly related, but it is vitally essential to decide what is to be accented in the analysis and what subject-matter is to be chosen. Of course, the issue of revealing the phenomenon of favoritism is very broad, as it comprises the analyses of mutual influences in the society: the dynamics of social processes, the changes of moral 
consciousness, state interests and, according to the role theory of personality, individual behavior.

Sociology is a synthetic science. If critics insist that a science must adhere to its subject-matter and its categories, the science would never leave the beaten track and reach new horizons. If it works this way, the controversy and conflicts of favoritism would be resolved only in certain conflict situations in single groups. Meanwhile, the society faces the challenge of "symbiosis of leader and favorite" at three levels: transnational (global), institutional and group levels. It is no coincidence that M. Olson notes that an organized minority can dictate their terms to a majority, and the majority cannot withstand it [4] (Olson M. 2012).

We can refer to the representatives of actor-network theory (ANT), [5] (Urry J. 2012), [6] (Lo J. 2015), [7] (Latour B. 2013), who broke the conventional division of subject-matters of sciences and arrived at a new vision of the social world. We realize that we are far from an integral complete study of the phenomenon of favoritism. There is also a risk of eclecticism: at times, the method has no complete clarity, categories of different levels are used, but the article merely aims at stating the problem of analyzing favoritism at three levels of sociology.

The sphere which tends to study the phenomenon of favoritism is, in our opinion, the sociology of knowledge, in the framework of which the value aspect, by Mannheim, is of vital importance. The object of study is the phenomenon of favoritism. The subject of research is the institution of favoritism, which includes role theory of personality. The method, to outline the multi-paradigmatic character selected by preferences, is the structural functional analysis. The role of favorites (an associate or a temporary worker) is defined via the assessment of their activities by groups singled out according to the type of their moral consciousness. The objective is mastering the force acting in the society - the phenomenon of favoritism.

Favoritism (from the French favoritisme) is a socio-cultural phenomenon of referring to a specific person or a group according to their leader's personal preferences. Favoritism manifests in services provided from below and benefits granted from the top. A leader delegates some authority to a favorite or his/her protégés, despite the existing official relationship of subordination established by a law or a tradition. Favoritism reached its triumph in the era of absolute monarchies, for example, the term $m-m$ de Pompadour as a 'royal mistress' appeared in those days. However, "a leader-favorite" symbiosis takes place in politics and continues up to this day, for example, the president's friend has the status of "the untouchable person".

Favoritism is a manifestation of human nature, subjectivity and selectivity. It is the phenomenon, with which the selected persons receive preferences from high-ranking officials in their relations with the others. In this way, favorites are most likely to have an opportunity to promote their ideas, implement their own goals and objectives. When we consider informal social relations, favoritism is particularly noticeable in case the relations degenerate into an impenetrable clan and stop the circulation of elites in the society. The laws of the phenomenon of favoritism work as an alienated force hanging over both the society and the personality. Science is intended to disclose these laws.

The object of the present research is the phenomenon of favoritism in the society. Favoritism as a type of social relation is a means of individuals' interaction in groups indicating people's different statuses shaped by latent stratification. The subject-matter of the study is the institution of favoritism. It manifests in group consolidation both of nations and of the majority of institutions and groups. In the social field, the institution of favoritism appears in the confrontation of social roles: "leader - favorite", "leader outsider", "favorite - outcast," "conformist - marginal", "outsider - outcast." The institution indicates the arrangement of roles and the dynamics of relationships in each community.

\section{The Necessity of Sociological Study of Favoritism}

Favoritism is a general social phenomenon, an attitude that permeates into the fabric of the society, and besides, forms the structure of the co-society. Favoritism is a process generated and generating "the clumps" of social roles, i.e. a type of social organization that we call institutions.

Some roles are formed spontaneously in the social institutions, others are formed consciously, rationally, purposefully, and the selection of "teams" and placement of persons supporting the leader from the bottom is formed spontaneously and by chance. Favorites are the bearers of the latent functions which are controlled neither in the collective, nor in the state or global community. "The discovery of the hidden features increase the importance of sociological knowledge, R. Merton said. ...The latent functions of certain activities or beliefs are not the property of commonplace consciousness, because they are unintentional and unconscious social and psychological consequences" [8] (Merton R. 1996).

In a modern society, a marginalized social structure becomes amplified downward social mobility of groups engaged in labor and a growing trend of permanent redistribution of property. The role of informal relations (communications) based on favoritism is being strengthened in the process of the competition for jobs and leadership positions in the enterprise management based on favoritism. The depth of this factor's "germination" in the society is not quite clear yet, but it is penetrated with family ties and friendship relations. A civil society needs to be aware of the measure of spontaneity and is to protect itself from it. It is important to identify the laws of the promotion of groups and individuals capable of governing the society. 
Favoritism as a social institution defines the social quality of society. It is the phenomenon that stops the development of science, culture, labor and production and generally prevents the progressive development of a society. It is necessary to determine the extent of informal relations within the institution, such as penance, community, cooperation or a member of the group, supported by a leader. The priority of group interests may promote the development of the country, for example, in the epoch of Peter the Great or the setting of aims by Donald Trump in the USA today. Thus, the core of the group is being formed with the leader at the centre and his associates. Nevertheless, there is another trend: barely educated favorites hinder the development of science, culture and production concentrating on personal enrichment. For example, P. Bourdieu considered both a real face of the state (moral and collectivist) and a real face of the officialdom (individual and interested in his / her status), which performs the function of a personality control by the state. The boundary between a devotee and a favorite is the priority of the social principle in social or economic interest groups among the devotees and the interests of an individual among favorites [9] (Bourdieu P. 2016).

Institution of Favoritism: The determining institutions define the parameters of social functioning of a society. In organizing institutions, groups and individuals create sanctioned social field. The group, as a rule, has an ability of self-regulation and self-government at the informal level. In fact, a close ring of a leader includes his followers and favorites. The favorites create the next ring of those who depend on him and the ring's support sustains him. Both the determining institutions and the organizing institutions form a supra-collective entity [10] (Bychenkov V.)

Role distribution in a team indicates the nature of the relationship of individuals in the group. The role, as we know, is regulated on the basis of common values of human behavior within groups, institutions and the international community. The role is prescriptions, expectations of behavior and requirements to a person. If a person takes part in the group (team) activity, learns the rules, frameworks and standards, then the latent, hidden hierarchy governs his/her behavior.

Favoritism is one of the basics of the social whole and signifies sanctions of a single type of communication at all levels of the social structure of the society. Favoritism is the type of communication which forms the social field at every level of the life of the society, not formally, but through tough sanctions regulating relations between groups and communities. In the communication, according to Durkheim, a group influences a person. Under the concept of favoritism, a favorite contributes to the cohesion elements of the society by a single-sanctioned field created by the favorite. Favoritism as a universal characteristic of the interactions is the archetype of the impersonal forces operating in a society, but it is not "divine power", not a fortune, but a mobile communication connecting people.

\section{The Theoretical Basis of Research of the Phenomenon of Favoritism}

A wandering, but not officially latching phenomenon, favoritism can be captured in the sociological knowledge network only through fractionating and differentiating favorites into positive and negative types. Dispositional personality structure is related to the role structure of the group. Such bulk compound analysis follows operationalization of role groups, and groups singled out according to the type of their moral consciousness. The typology is not obliged to meet the requirements for classification. A classification should break a wide range to smaller items without residue. However, the allocation of at least one type of the mass of the analyzed appearances is an instrument of heuristic analysis. Along with one of the trends allocated in the sociological literature, it is an appeal to the man, his past and future, to the peculiarities of his personal experiences and his vital strategy.

Sociological approach to the study of the social identity problem belongs to Jenkins, R. He wondered "how we learn, who we are, and how others identify us?" and "How do historical, ideological, and cultural factors influence the way people build a part of their identity 'in groups' and 'out of the group' " [11] (Jenkins, R. 2008).

Within the framework of psychosocial approach to the study of social identity H. Tajfel studied the process of social and group categories transformation in the category of self-awareness [12] (Tajfel H. 1970).

Social and socio-psychological mechanisms of formation of the social identity of the personality are studied by Leningrad sociologists under the direction of V. Yadov [13] (Yadov V. 2000).

The Imitation theory of the French sociologist Gabriel Tarde explains that all the achievements of civilization are the result of great personalities' activities, and the main law of social life is the imitation of a hero by the crowd [14] (Tard G. 1996).

In his conception of "heroes and crowd", Mikhailovsky argued that the psychological impact of the individual depends on the mass perception, and, in general, any personality, and not necessarily an outstanding personality, being accidentally in front of a crowd, can play an important role in certain events. N. Mikhailovsky distinguishes the concept of "hero" and "great personality". While a "great personality" stands out of the crowd and is determined by the value of his/her contribution to the society, a "hero" is a person who takes the first step and becomes imperative for the crowd. The crowd follows the hero, regardless of his moral characteristics [15] (Mikhailovsky N. 1998).

The conception of a critically thinking personality helps to explain how a personality affects the progress of the society. P. Lavrov put forward the idea that a critically thinking personality is a bearer of the moral ideal which is introduced into the consciousness of the society [16] (Lavrov P. 1967).

Ch. Cooley considers the phenomenon of the leadership 
through a personal power, he identifies two factors: a comparative evaluation of consciousness and a constructive and fruitful impact on the other leader. "Being an outstanding personality and, consequently, the leader means, on the one hand, to be a strong personality, but on the other hand, the ability to experience deep sympathy; these are the two personality scales, rather than any individual quality" [17] (Cooley Ch. 2000). Cooley could not avoid the question of the role of personality in history: the individual is "the result of heredity and social factors". "Whether we believe in the spiritual essence of Christ's teachings or not, scientific sociology, I believe, does not contradict Christianity in whether his life radically changed the course of history... No one can say what would have followed the French revolution and what the further history of France would be like, if not for Napoleon. One thing is clear - everything would have been very different" [17] (Cooley Ch. 2000).

G. Plekhanov wrote in his article "On the Role of the Individual in History" that a personality, due to the features of his/her character, could influence the society. Sometimes this influence is very significant. The character of the personality is a "factor" of the society development. A personality can show his/her talents only when it is necessary to take this position in a society. To be able to affect the history of the society, he/she must meet the following two conditions: his talent must comply with the relevant social needs of the epoch: if Napoleon, instead of possessing a military genius, possessed Beethoven's musical talent, he certainly would not have become an emperor. Second, the existing social order must not bar the road to the personality having this feature, necessary and useful precisely at this time [18] (Plekhanov G. 1961).

Something homogeneous in the phenomenon of favoritism can be represented as the quality of monitoring and the number of relations between heterogeneous elements. The role theory covers such units as the assessment of social groups in the areas where favoritism develops most often; it is an appeal to the civil society consciousness and to the ruling elite with the recommendations. This is an estimate of favoritism from the position of each role group, and, finally, the determination of their personal perspectives and preferred role in the future.

Why is it possible and should be affirmed that favoritism has a 'social dimension'? If favoritism was a sphere of social and psychological relations, the interaction of the satellite countries would subordinate a set of laws that a few people read. It would be a curious side of the relationship of political and religious leaders with time-servers and favorites. However, favoritism as a latent form of organization is, by Emile Durkheim and Randall Collins, ritual (material, substrate-related, behavioral side) and symbolic - the perfect party that unites "friends" and "foes". The distribution of wealth, the disposal of the life and death of other people depends on the symbiosis of 'leader - favorite'. Dividing, as ancient as the world, into friends and foes forms values, and values become the ideology. The ideology tied to the territory, becomes a favorites' priority. The doctrine finds its executive functionaries in a rationally organized bureaucracy. The Bauman's 'urgency of the Holocaust' has not been canceled [19] (Bauman Z. 2013).

We all know that favoritism as bureaucracy, according to Collins, creates some inconvenience, but we do not know why it operates in this way [20] (Berger P., Berger B., Collins R. 2004). The presentation description should highlight the three levels of favoritism: social, group and personal. Accordingly, the select group of "leader - favorite", "conformist - marginal", "outsider - outcast".

The individual and the group is a material substrate, which is the bearer of social relations. Conjugation informal structure and function in the current professional stratification is a role. The existence of favoritism in the team indicate the gaps between expected and inappropriate behavior, in accordance with the role, individuals for the roles of self-defined man's place in the group.

The connotation of the concept of "favorite" is negative. Favorite (from English favor - goodwill) is the person who enjoys the favor of the ruler, a powerful person, receiving from him various privileges and, in turn, having an influence on the leader.

The phenomenon of favoritism does not remain unchanged in an era of intensifying crises. People are often discovering the impotence before this alienated force gets to hang over them. Ties between theory and empiricism, the ratio in the history of the companions and favorites, favorites and minions, the yield in the field of sociological research reveals rich in n-dimensional living space unanimity of respondents in understanding the elusive phenomenon of favoritism.

\section{The Methodological Bases of Study the Phenomenon of Favoritism}

The methodology of the analysis and the method of research are always based on the objective characteristics of the inspected object. The object of the research is favoritism - the latent patronizing attitude to a leader's favorite. The subject matter of the analysis is the institution of favoritism. The research method is identification done by the respondents to role groups. They had to assess the level of favoritism in communities of socio-demographic and territorial groups, as well as favorites' temporal characteristics. The presence of favoritism in a team is verified by the presence of an outcast (pariah) in the same team. Attention is paid to the attitude of role groups and groups singled out by the type of their moral consciousness (socio-ethical groups) to favorites, as these assessments vary considerably.

Communitarianism is the type of social communication on an individual or collectivist basis. The symbolic level of favoritism analysis focuses on the assessment of the 
historical and contemporary favorites in various areas of society. The practical level (ritual) of the analyses highlights the social aspect of favoritism.

Personal traits of a favorite are: the superiority over the surrounding people achieved by the manifestation of energy; activity (awareness, diligence and ability to intrigue); the will to power, even with lack of education; a passionate desire to convert their own abilities into wealth, honors and fame (popularity of becoming widely known).

The categories "situationality", "systemic differentiation", "contingency", "irritations", "double contingency" by N. Luhmann serve as elements of a synergistic approach to the research of the sociology of favoritism [21] (Luhmann N. 2006). The process of differentiating the system allows to clarify the qualitative characteristics of a favorite. As a result, there is an opportunity to get not a flat, but an n-dimensional (multi-layer) picture of the phenomenon of favoritism. Role groups give a differentiated assessment of favorites. This is necessary to show the purpose of this community (collective), and how much favoritism restrains the realization of common aims.

The distribution of data according to personal characterization is a way of getting away from abstraction to the knowledge of the nature of favoritism by the specific carriers of institutional roles. It is possible to symbolically define the invisible and strictly hierarchic structure of human relationships, and resorting to the substrate-event aspect of the team activity, to reveal the contradictions of the process and the roles of performers: leaders and favorites; conformists and outcasts; outsiders and outcasts, both in the current situation and in the near-term outlook. The comparative analysis allows us to outline changes and tendencies in social attitudes. Besides, it is essential to reveal the attitudes of groups singled out by their type of moral consciousness to leaders and favorites in the following social spheres: political, economic, military, religious and ideological ones.

The operationalization of the phenomenon of favoritism as an informal institution establishment becomes a reality on the basis of:

(1) revealing the role of a favorite through the method of self-identification, definition of the meaning of existence of this role, incentives, motives and interests of the favorite;

(2) compound differentiation from other possible and real roles;

(3) realizing the groups' attitudes to a favorite;

(4) investigation of the circle of "favorite" features of the individual, the group that show correlations and the respondent's attitude toward favoritism;

(5) outlining "favoritism" as a type of communication and the active essence of a favorite's magnitude;

(6) outlining those aspects of the structures and actions that reveal the essence of favoritism in a variety of its phenomenal features;

(7) fixing the measure (maximum or minimum share) of favoritism in the areas such as politics and ideology, science and art, trade, labor, sports, school education, daily life;

(8) differentiating the semantic representation of the role of favoritism and its actual presence in a collective or team.

Favorites are defined according to the following major features:

1. Belonging to the core around the leader;

2. Presence in the circle of people around the leader;

3. Involvement into the circle of the ruling elite;

4. Highly demanded personal qualities; a role of a favorite in the team management;

5. The place and role of the respondent in a social group;

6. Favorites in: ideology and politics; the military sphere; Institute of confessions; social field of economy and production.

In describing each group of roles we are to find out, on the internal logics of each group, the share of their manifestation in order to understand their logics of evaluation, role groups' independent views and the description of their new associations. It is necessary to clarify the phenomenon of favoritism that has not been the object of sociological analysis so far.

The favorite either ascends or descends in the elite circulation [22] (Pareto V. 2003). Essence, which is measured by favoritism, quanta changes, living their own lives: every social product - ethics and language, art and science - "tends to multiply itself in thousands of millions of copies, wherever there are human beings", according to B. Latour [23] (Latour B. 2014).

Assessing the social and socio-psychological attitudes we used the principle proposed by N. Luhmann [24] (Luhmann N. 2007): irritation, differentiation and double contingency. The point is regarded as the motive that drives the direction of activity of the person. The ethical and axiological aspect of the problem is the search and definition of the meaning of the concept of social life to identify historical (individual and group) forms of favoritism, according to Scheler [25] (Scheler M. 2011).

Identifying the attitude of social groups to favoritism, we questioned the following groups of respondents: humanitarian intellectuals, technicians, workers, employees, students and pensioners. The respondents were asked to define what favorite personalities played a positive and a negative role in the past and in the present: a) modern favorites: democrats, strategists, ideologists, oligarchs, political, military and religious leaders, women involved in social and public activities; $b$ ) historical favorites: associates, timeservers, including such as the "new man", "citizen of the world"; c) wives and mistresses of the royalties [26] (Shossinan de Nogaret G. 2003).

The respondents valued modern favorites higher than historical ones. The main epistemological problem of the sociological analysis L. Floridi saw in combining «big data» and small patterns [27] (Floridi L. 2016). The method of research is based on a synergistic approach and includs 
elements of comparative analysis, namely an intra-comparison of the objects of research, and going beyond the system in analogies, parallels, comparisons with other systems, in macro-, meso- and micro-levels of the phenomenon of favoritism. The theory and practice of favoritism should be viewed as a complex area of knowledge about the specifics of the sociology of morality, but integrating with the economic sociology, sociology of knowledge, social psychology, social anthropology and sociology of culture.

The objectives of the study include the definition of the essence and the existence of the phenomenon of favoritism as the characteristics of social ties covering all spheres of the life of the society; the identification of the problems and conflicts of social groups in connection with the manifestations of favoritism described in literature, while other aspects of research are waiting for their careful consideration in future.

\section{Indicators for Analyzing the Phenomenon of Favoritism}

Methodically, we associate favoritism relationships with the concepts of "social order" (function and dysfunction), the process of carrying out "social dimension" differentiating (for roles and types), and we present the respondents' evaluation of "social practice favoritism". Comparing the ratio of groups of favoritism on the socio-demographic characteristics and socio-professional structure, we identify those spheres of social activities in which favoritism is expressed most vividly.

The objectives and the tasks of the research are to identify the relationships of favoritism in order to determine its impact on the social reality. We fix a measure of respondents' awareness of favoritism at the global, institutional and collective levels of the society, as reflected in the macro, meso- and micro-levels of the research theory.

The communication-type system in a social group is determined by the symbiosis of a leader and a favorite. It is sustained by a weighty mass of conformists and marginal groups, but is simultaneously undermined by the opposition of outsiders, thus undermining the unity of the whole system and turning it into dynamic motion.

The typological (by type of moral consciousness) and role (for latent hierarchy in a team, community) levels of the analysis allow us to describe a real understanding of the place of favoritism groups in the major areas of life. The synergetic volumetric representation of the phenomenon of favoritism in some approximation to reality, inherent in the method of the studied phenomenon, namely, the dual role of social structure and ethical consciousness, is a combination of the two projections.

Defining the boundaries of the phenomenon of favoritism in theory facilitates the transition from managing destructiveness (clan and clientele, sinecures, "plankton", etc.) to a different type of controlled bottom-social type of organization "Community" and the groups on the basis of the studied patterns. Therefore, the study of favoritism promotes greater self-knowledge society, revealing hidden informal structures operating with the power of natural laws and the subordination of the rational will force in the society.

Favoritism, in the most general sense, is a situation in which favorites preferred by a leader rule all the vital spheres of the community and society. A leader, a ruler or an influential and powerful in a certain field person determines the type of social interaction and literally leads. The leader is a head, either of a political party, public organization or the labor collective, the religious community, family, or other organizations. It is a person who enjoys great prestige in any group. Luhmann is right to observe that the question "can be answered only by resorting to self-description and the internal identification system" [28] (Luhmann N. 2007). However, a favorite contributes to the fact that "the environment makes the king" and affects this process binding the leader, his entourage and the crowd into a single whole.

The typological (by type of moral consciousness) and role (for latent hierarchy in a team, community) levels of the analysis allow us to describe a real understanding of the place of favoritism groups in major areas of life. Synergetic volumetric representation of the phenomenon of favoritism in some approximation to reality, inherent in the method of the studied phenomenon, namely, the dual role of social structure and ethical consciousness, is a combination of the two projections. The method of social research dynamics of Moral Consciousness is interview and questionnaire. During 1980-2012, we examined 34 establishments for our research, $\mathrm{N}=11111$ by the example of Middle Ural regions [29] (Paramonova S., 2012).

Communitarian keeps a fragile equilibrium between the norms, oriented to active creativity, and the new background expectations of the society: the principle of payment in accordance with labor and the equality of initial possibilities on the one hand, and the equality of all in the face of the law, on the other hand. A communitarian responds to the challenges of the time with an active help in different life and working situations equally to those who ask for help and those who need help. His ability to self-development is expressed in his understanding of freedom as internal purposefulness, the realization of the abilities, in spite of the external circumstances, the personal characteristic of communitarian type. The true history of a person considers the aspiration to change the life, to plan it consciously. The personal characteristics of a communitarian are defined first of all by the fact that women show such type of consciousness and behavior more often than men. That fact proves the data obtained from mixed and "female" enterprises. Men are usually pragmatists. Their education and profession are not strictly connected with the type of their moral consciousness. A communitarian has a family and is an authority for children. He tries to maintain the 
feeling of love in family. The ability of the person to make good and kind actions is supposed to be a free moral act and to create kind things is available to everybody, but in the reality this is the peculiarity of communitarians. Favoritism isn't characteristic of a communitarian. Most favorites are pragmatists, in other cases they are hedonists or of transitional types.

The transitional type of moral consciousness: His activity is especially widely manifested in big cities. In the conditions of the changes of the values of the society women showed "spiritual migration" to the group of transitional type, and constituted a third part, which is not characteristic of the ethics of the sex in the organic epoch, but it is typical for the transitional period. It constitutes a half among the marginal types in the working groups of the society in the quantitative sense. The characteristics of the transitional type of moral consciousness are largely defined by his place in the social structure of the society. Most often he is a leader at the most important, initial level of management. In his value attitude to labor in comparison with other transitional types he has revealed the highest orientation to creation and self-perfecting, which is similar to a communitarian. The high orientation to earnings unites him with pragmatist. The spirituality in the consciousness of the transitional type creates continually, charged with "duality". His emotional conviction in the aspiration «'to have' instead of 'to be'» here are only substantiated by the rationalizations.

Hedonist: The sense of life of hedonist is getting pleasure and enjoyment. The faith dominates in his consciousness. Hedonist gravitates towards family and narrow circle of friends. They have a higher education. By the social origin they come from humanitarian intelligentsia. They refer themselves to the middle-paid employees. Their places of work are the state enterprises. If hedonist changes his work, he comes to service sphere. The personal features of hedonist: Mostly women are drawn to hedonism. The hedonism of women is connected with their fertile period. However where there is a favorable mode for the men, due to the limitation of the acceptance of women, the share of the hedonists-men becomes bigger, than among the women. Among hedonists there are mostly healthy women and men. On the one hand here there is the factor of their origin and the self-removal from the intensive work; on the other hand hedonist consciously maintains his health. The representatives of this group by the type of moral consciousness are mostly worried about the sanitary-hygienic working conditions at the enterprise and the ecological situation. There are more hedonists than pragmatists among the youth. Very often hedonists have a low qualifying category and the lowest the parameters of performance standards. Hedonists praise the values of cooperative nature more, than the values of competitive nature, which characterize a person as a rival. The criterion of choice in the case of discomfort for them will always be the opinion of the collective, which they listen to keenly and adherently. Hedonists help only when they are asked for help. In getting higher education hedonists concede to the transitional type and a communitarian. In the case when hedonism is actualized over the limits of the possible, the activity of a person and whole communities will lead to their destruction. Since hedonist is driven towards the values of traditional society, justice in his understanding is inseparably connected with the moral qualities, which are to predominate in the life of people. It is impossible to be fair, without being humane. His orientations are directed to the trust in the authority. In a society of consumption and glamorous capitalism the hedonist is a favorite.

Pragmatist: Pragmatist is the bearer of the model of economic rationality of the society. He believes that the principle of historical justice is the equality of all in front of the law. Besides, four components of freedom shape his spirit: to do everything that is not forbidden by the law; the inner subjective freedom; the non-interference of the State into the private life of a person, and also the availability of the money, the mammon, the property. The closer to the financial and industrial centers the community is situated, the higher is the level of pragmatism of the interrogated respondents. In general pragmatists are men. Women have constituted the smallest part. The personal characteristic of pragmatist: Very often pragmatists come from the families where parents belonged to the underpaid groups of the society. A part of pragmatists is from the circle of intelligentsia. This group has promoted at the enterprise due to their education. Another part of pragmatists is from the families of unskilled workers. The values of individual material interest were common to these groups, opposite in their educational level. People with different types of moral consciousness show themselves in friendship in different ways. The circle of contacts of pragmatists is limited to "the necessary people". Pragmatist renders his help mostly to those people, who either ask for assistance or who can answer equivalently. Men-pragmatists have revealed a high satisfaction with their promotion at each enterprise. The leaders of high rank are, as a rule, pragmatists [30] Paramonova S. 2015].

Defining the boundaries of the phenomenon of favoritism in theory facilitates the transition from managing destructiveness (clan and clientele, sinecures, "plankton", etc.) to a different type of controlled bottom-social type of organization "Community" and the groups on the basis of the studied patterns. Therefore, the study of favoritism promotes greater self-knowledge society, revealing hidden informal structures operating with the power of natural laws and the subordination of the rational will force society.

A favorite is a carrier, an organizer and initiator of relations of favoritism. He acts as a conductor between the leader and the team. His most prominent feature is the creation of a managed and sanctioned social field. Favoritism is a form of self-affirmation of a subject who has reached the status of a favorite. Self-preservation and self-assertion are expressed in the presence of privileges. Privileges protect a favorite from self-destruction, criticism, negative reactions and create an aura of benevolent attention of others, but most 
significantly, they provide opportunities for self-realization and implementation of the proposed initiatives.

The core of the followers is formed around leaders. The stronger the favorite individual's qualities are, the less important are other components, for example, professional ones. A favorite is a special characteristic of a person. A favorite looks in the eyes of the down-line elect of fortune, the manipulator reaching power through the influence of the powerful. Favoritism reveals itself as a socio-psychological phenomenon, it expresses the same type of authorizing social communication, forcing the elected specifically play a role in the global political community, and in a narrow range in the team. The function of the latent social sanction of the field determines the position of "the best of us", "our man - not one of us". Psychologically, negative, hostile energy results in groups of rejection - "rogue state."

Socio-psychological aspect of the analysis: Never before has not been subjected to an institutional audit of the Company competence and professional skills of the leaders and favorites, hence spontaneous, dysfunction in the production and management of the company. If dysfunction is - a violation of the order, the chaos of this - is the lack of order. Favoritism functions as a type of uncontrolled ties at all levels in important areas of life.

Socio-political aspect of the analysis makes it possible to reveal the essence of the favorite and removed mystifying veils "giftedness" phenomenon favorite one and prevailing opinions about alleged "incompetence" of the other. Favorites really stand out special qualities that do not occur at all. Some favorites are endowed with intelligence, others physical strength and attractiveness - beauty; third generalship vain, courage; fourth - the ability to intrigue. Other - endowed with life experience and confidence judgments in all circumstances and vicissitudes of fate. Moreover, almost all the favorites have great stamina. Stamina as myself craving significance be if someone, are common to all countries.

Socio-political aspect of the analysis makes it possible to reveal the essence of the favorite and removed mystifying veils "giftedness" phenomenon favorite one and prevailing opinions about alleged "incompetence" of the other. Favorites really stand out special qualities that do not occur at all. Some favorites are endowed with intelligence, others physical strength and attractiveness - beauty; third generalship vain, courage; fourth - the ability to intrigue. Other - endowed with life experience and confidence judgments in all circumstances and vicissitudes of fate. Moreover, almost all the favorites have great stamina. Stamina as myself craving significance be if someone, are common to all countries. Stefan Zweig was investigating the story about the historical figure Joseph Fouche who was a favorite - courtier an unscrupulous businessman, who had made a huge fortune by plundering the churches during the Great French Revolution. He sent the royal family of Louis XVI to the guillotine. During the reign of Napoleon Bonaparte, Joseph Fouche held all the threads of power in his hands.

When the counter-revolution and the party of the royalists triumphed, he found a way to Louis XVIII, exchanging his salvation for the status of the Minister of Police. He was also proposed to carry out the execution of the heroes of the Napoleonic military campaigns. He made up the list of all his former friends to be executed. Being the richest man in France, Fouchewas exiled to Czechia as a diplomat. Later he was exposed to the contempt on the part of a secular society. Thus, a former favorite became an outcast [31] (Zveig S. 1993).

Some favorites are at their position deliberately, career aspirations, others - thanks to the charisma, the third group by accident, close to the ruling lady (or a leader in a particular field of activity). In other words, due to the status social position and informal ties up the social ladder in the conditions of the elements can move and make decisions, stopping the development of the country, a person who does not have outstanding abilities and talents and high moral character, just that he supports weakening the state, myopia leader, the favorite, took possession of the power of the existing hierarchy in a vibrating uncertainty of the situation.

The mechanism of favoritism: Mechanisms of maintenance and reproduction of favoritism triad include: status in the field of activity; the selection frame on the principle of devotion; Association "Leader - favorite" on the basis of privilege, superior norms and rational assessment. Areas of varied manifestations of favoritism: labor and production, education and politics, the establishment of the titular nations.

A favorite is a "conductor" between the leader and the masses, a favorite leader, influencing him and enjoy privileges, material and spiritual wealth. The concept of "favorite" has a negative connotation. This selects from the crowd - a successful, charming, and obsequious. K. Birkin in his original study noted: "the thick-skinned and the first capital of every virtue it to go parasite favorites" [32] (Birkin K. 1992).

A conformist is a person who agrees with the opinion of the majority even if they believed their opinion is erroneous, it cannot withstand the pressure of the majority. Conformists differ from other members of the public manifestation of the most high, depending on the group in specific situations. Conformist fulfills its role, approaching as closely as possible to the institutionalized expectations. Conformist passive participant, avoiding responsibility and striving to remain unobserved. Conformist - personality, uncritically receptive group norms and the authority of the leader. Conformist, as a base figure of generality of any order, holds a group of the team.

A marginal is a person, located on the border of different social groups, human. "Margot" - Eng. - "Edge" may be a person enters into a large community than his small group. But here and there he is on the borders of these groups. The concept of marginal personality developed in the Chicago School of Sociology R. Park. R. Park, referring to the 
marginal position of the individual talents of members of national minorities, concluded that the marginalized social groups contribute to the formation of creative abilities and creative achievements. The poor adaptation to the system of values of the dominant group, without causing the interest to acquire these values, it leaves a large potential for creative achievement. Marginal is a person who has lost the old social links, located on the periphery of their social environment, not adapted to the new conditions of life and has no stable social status. Marginal activities and actions crack codes [33]. (Bankovskaya S.P. 2002)

Sociological analysis of the conversion of outsiders in the leading group in the transition period held U.N. Davidov. He noted that one way of collapsing human life and do not install another ... "outsidership" could not even work out a world view, it is quite adequate own being. Outsider found narrow, but from year to year growing intellectual environment - in consequence she called themselves the elite. In the second half of the XX century, philosophers, sociologists, culture experts noted the existence of so-called "hostile culture", leading descended from such famous "outsiders of the past" as the Marquis de Sade, Arthur Schopenhauer and Friedrich Nietzsche. They continue the line of "revaluation of values", they have to live only by being destroyed. An outsider is "thrown" into the world of an alien culture only to disintegrate it from within [34] (Davidov U. 1989). In the spiritual life it meant the transition from classical to post-non-classical rationality. The information flows of outsiders were caught up by the ideologues of these nations who were ready to monstrous moral and military disasters.

In today's daily life the role of an outsider is unattractive. The leader is always more successful than others in the great social game of life. And it does not mean that it is more honorable man than others. It can be lifted upward team just disposal of the former leader. Outsider - the exact opposite of the leader. He considers himself more than worthy of a better position in the team, but the less fortunate man whose whole life - a chain of unrealized potential, which, he believes, have no luck in life. He often claims to be the favorite here; he would have felt "on the spot". Outsiders sometimes becomes a favorite, he is basking in the glow of another's glory, but at night, grinding his teeth with envy to the leader. This kind of change their informal status, may become hazardous. It can become a dangerous enemy leader, and secret. Among the groups employed in labor, outsiders most often refer to the transitional types of moral consciousness.

The outcast (rogue) opposed to the favorite. An outcast (pariah) in any social group or community is subjected to disapproval and sanctions. An outcast is barred from contacts and interaction and is doomed to ostracism. It is a personality at the margins of a group, by his status, even farther from the core of the group than outcasts. An outcast is a person who has lost, by force of circumstances, his usual position in a group and finds himself completely outside the group, condemned by the symbiosis "leader - favorite". Because of the provisions reigning in the group, he would never be able to ascend and change his status. To change the group seems to be the only possible way out. We find Jean Valjean as an example of outcasts in literature and Socratus and Christ as examples from history. They were shunned, but then worshiped and some have been worshiped by the humanity for centuries already. The research shows that among the employees' outcasts are mostly communitarians and hedonists. The method of social research Sociologe of Favoritism is questionnaire. During 2003; $2012 \mathrm{~N}=1580$; by the example of three regions Russian Federation. Consider using SPSS data packet [35] (Paramonova S. 2012).

In the analysis process to be considered the differentiation of role positions in the group, they connect with types of moral consciousness. The meaning of the activities of each group viewed from the internal logic of the development of role-playing groups, together with each role group's valuation of role of the favorite from the outside. General methodological level of favoritism is raised to a fixed level of psychology of communication and policy on a global scale. Institutional characteristics of the phenomenon of favoritism relate to the role group, and territorial settlement. Empirical level of analysis reveals the symbolic and behavioral logic of each type. Comparison of dispositional-role characteristics involves identifying patterns in the combination of large and small samples, this leads to the assessment of the personalities of favoritism.

\section{Conclusions}

Favoritism is the type of communication that forms social fields at every level of society. As part of the informal structure of interactions in the society, favoritism imposes sanctions upon the relationships in all types of communities, from religious to secular, from the political groups, "formatting" the story, to the creative and labor collectives, from the whole society institutions to large and small social groups. On the surface, the mass consciousness favoritism acts as a socio-psychological phenomenon, but in its essence, it is the area of social relations that, with the power of natural laws, have an impact both on an individual and the whole society.

The problem of favoritism is extremely broad and covers many social phenomena. Favoritism involves a lot of concepts from psychological, sociological and socio-psychological methodological approaches. In this article we have reviewed some sociological and socio-psychological aspects of the study of favoritism. Favoritism in the past, today and future is a significant problem of latent relationships of personalities in all communities, as well as institutional manifestations. Favoritism demonstrates its latent function in the ratio of global leaders and their satellites in the "game" and associations of the unions. In terms of the favoritism theory, the problem of favoritism analyzes and uses the concepts of 
the role of personality in history, particularly in the historical sociology. As it is shown in the article, the favoritism issue covers three levels: macro-, meso- and micro-levels of the analysis. Sociology studies the attitude of groups and strata to favorites. The phenomenon of favoritism is the latent function of the society, and it was R. Merton who promoted the examination of these functions. The essence of the favorite is to create a sanction social field and become the second power in the team and the community.

Favoritism, to a large extent, is the driving force of history. This phenomenon, close to our time, was rooted in antiquity. The characteristics of human relationships (whether they are selfish and hedonistic, materialistic or just friendly) are something that can influence the events and determine the fate; rule the countries and states, ultimately, the lives of people. On the one hand, favoritism as a strategic reserve of leadership is the potency of society, and on the other - to restrict the creative activity of others - is the core of the symbiosis of "leader - favorite" team members and the society as a whole.

\section{REFERENCES}

[1] Weber, M. (1990) Protestantskaya etika i «duch» kapitalisma. Izbrannyie proizvedeniya (per. s nem. i predisl. U.N. Davidov. Predisl. P.P. Gaydenko). Moscow. Progress. S. 44-27 [in Russian].

[2] Wallerstein, I. (2016). Mir-sistema Moderna I. T.1. Capitalisticheskoe selskoe hosaystvo i istoki evropeyskogo mira-economiki v XVI veke (red. G.M. Derlugyan, per. s angl., liter. red., comm. Protsenko N., Chernyaev A.). Moscow. Russkiy fond sodeystviya obrasovaniu i nauke. 2015. $552 \mathrm{~s}$. [in Russian]

[3] Manheim, K. (1994 ) Ideologiya i utopiya. Diagnos nashego vremeni (per. s nem. i angl. Levinoy M.I., Karpushina S.V., Milltr F.I., Studenikinoy T.I.) Moscow. Yurist. S. 52-94 [in Russian]

[4] Olson, M. (2012) Vlast i prozvetanie: Pererastyaz rommunistizcheskie b kapitalistizcheskie diktatury (per. s angl. B. Pinsker). Moscow. Novoe izdatelstvo. 212 s. [in Russian]

[5] Urry, J (2012) Mobilnosti (per. s angl. Lasarev A.V., vstup. st. Harlamov N.A.) Moscow. Izdat. konsald. Gruppa Praksis, 576 s. [in Russian]

[6] Latour, B. (2013) Nauka v deystviy: sleduya za uchenymy i za inzchenerami vnutri obschestva (per. s angl. K. Fedorovoy; nauchn. red. S. Milyaeva). Sankt-Peterburg. Izdatelstvo Evropeyskogo universiteta v Sankt-Peterburge. 414 s. [in Russian]

[7] Lo, J. (2015) Posle metoda: besporyadok i socialnaya nauka (per. s angl. Gavrilenko S., Pisarev A. Hanova P. Nauchniy redaktor perevoda S. Gavrilenko). Moscow. Izdatelstvo Instituta Gaydara. 352 s. [in Russian]

[8] Merton, R. (1996) Yavnyie i latentnyie funczii. Americanscaya Sociologiya: Texts (per. s angl. U. Aseev).
Moscow: Universitet Internationalnogo Bisnessa i Menegmenta. S. 393-461 [in Russian]

[9] Burdye, P. (2016) O gosudarstve: kurs lekciy v Kolledzch de Franc (1989-1992) Pyer Burdye; [red.-status. P. Champagne, R. Lenoir, F. Pupo, M.-C. Riviere]; (per. s fr. D. Kralechkin i E. Kushnareva; predisl. A. Bikbov). Moscow. Izdatelskiy dom Delo RANH i GS. 2016. 720 s. [in Russian].

[10] Bychenkov, V. (1996) Instituty: Sverchkollektivnye obrasovaniya i beslichnye formy socialnoy subjektnosty. Moscow. Rossiyskaya Academiya sozialnych nauk. 776 s. [in Russian]

[11] Jenkins, R. (2008) Social Identity. 3rd Edition, 246 p.

[12] Tayschfel, H. (1970) Experiment in intergroup discrimination. Scientific American. Vol. 223.

[13] Yadov, V.A. (2000) Strategiya sotsiologicheskogo issledovaniya. Opisanie, obyasnenie, ponimanie sotsialnoy realnosti. Moskov. Dobrosvet. 596 s. [in Russian]

[14] Tard G. (1996) Sotsialnaya logica. Sankt-Peterburg. Sotsialno-psichologizcheskiy centr (sostavlenie i obsch. red. Bobneva M.I., vstupit. st. Andreeva G. M.) 501 s. [in Russian].

[15] Mikhailovsky, K. (1998) Heroi i tolpa. Sankt-Prterburg. Aleteya. 406 s. [in Russian].

[16] Lavrov, P. (1967) Historical Letters (per. Scanlan. J.P.) Berkeli. Los Angelos. Univ. Californiya Press. P. 113.

[17] Cooley, C. (2000) Chelovecheskaya priroda i socialniy poryadok (per. s angl. pod obzch. nauchn. red. Tolstova A.B.). Moscow. Ideya-Press, Dom intellectualnoy knigi. 320 s. [in Russian].

[18] Plechanov, G.V. (1956) Izbrannyie philosophskie proisvedenia. Soch. v 5 T., t. 2. Moscow. S. 300-334 [in Russian].

[19] Bauman, Z. (2013) Actualnost Holokosta (per. s angl. Castalskiy S. i Rudakov M.) Moscow. Izdatetelstvo Evropa: ID KDU. 316 s. [in Russian].

[20] Berger, P., Berger, B., Collins, R. (2004) Lichnostno-orientirovannaya sociologiya (per. s angl. V. F. Anurin). Moscow. Akademischeskiy Proekt. 608 s. [in Russian].

[21] Luhmann, N. (2006) Differentsiatsiya. (per. s nem. B. Skuratov). Moscow. Logos. 320 s. [in Russian].

[22] Pareto, V. (2003) Kompendium po obschey sociologii (per. s ital. A.A. Zotov, nauchniy red., predisl. M.S. Kovalova). Moscow. Izdatetelskiy dom GU Vyschaya schkola economiki. 512 s. [in Russian]

[23] Latour, B. (2014) Peresborka sotsialnogo: vvedenie v actorno-setevuyu theoriu (per. s angl. I. Polonskaya). Moscow. Vyschaya schkola economiki. 384 s. [in Russian].

[24] Luhmann, N. (2007) Vvedenie v sistemnuyu teoriyu (per. s angl. K. Timofeeva). Moscow. Logos. 360 s. [in Russian].

[25] Scheler, M. (2011) Problemy sotsiologii znaniya (per. s nem. A.N. Malincin) Moscow. Institut obzshegumanitarnich issledovaniy. 320 s. [in Russian].

[26] Shossinan de Nogare, G. (2003) Povsednevnaya zshizn zshen i 
vozlublennyich franzuzskich Koroley (ot Agnessi Sorel do Marii Antuanetty (per. s fr. S.V. Archipova). Moscow. Palimpsest. 249 s. [in Russian].

[27] Floridi, L. (2016). Big data and epistemological challenge, 25 (4): pp. 345-437. Bolshie danniye i epistemologizscheskiy vizov, (obsor Chlebnikov G.V.). Moscow. 'Referativniy Jurnal Socialnych i gumanitarnych nauk. otezchestvennaya i sarubezchnaya literatura'. Seriya 31. s.13-17 [in Russian].

[28] Luhmann, N. (2007) Vvedenie v sistemnuyu teoriu (per. s angl. K. Timofeeva). Moscow. Logos. 320 s. [in Russian].

[29] Paramonova, S. (2012). Dinamika moralnogo soznaniya (Vvedenie v sociologiyu morali). LAP LAMBERT Academic Publishing GmbH \& Co. KG, pp: 443. [in Russian].

[30] Paramonova, S. (2015) Types of Moral consciousness. Mediterranean Journal of Social Sciences. Vol. 6. No. 5, October 2015 Suppelement 4. Rome, Italy. Pp. 84-89.
[31] Zveig, S. (1993) Josef Foushe (per. s nem. P. Berstein) Stephan Zveig. Sobranie sotchineniy v semy tomach. Tom chetvortiy. Moscow. Pravda. Pp. 395-623 [in Russian].

[32] Birkin, K. (1992) Vremenzchiki i favoritki XVI, XVII, XVIII stoletiy. Kn.1. Moscow. Author. 272 s. Kn. 2. Moscow: Author. 272 s. [in Russian].

[33] Bankovskaya, S.P. (2002) Robert Park: evoluzionno-reformistskiy podchod $\mathrm{v}$ socioligiy. Istoriya teoretizcheskoy sotsiologii. V 4 t.T.3. Moscow. Nauka. S. 127-128 [in Russian].

[34] Davidov, U.N. (1989) Etika lubvi i metafisika svoevoliya: problemy nravstvennoy filosofii. Moscow. Molodaya gvardiya. 317 s. [in Russian]

[35] Paramonova, S. P. (2012) Symbios lidera i favorita v socialnoy strukture grupp. Journal Diskussiya. No 7 (25). S. 75-81 [in Russian]. 